\title{
Long-Term Prospects for Landscape
Mitigation Programs
}

\author{
Sarah H. Schlanger 0 , Signa Larralde, and Martin Stein
}

\section{ABSTRACT}

The alternative mitigation program that the Bureau of Land Management (BLM) established in 2008 to address impacts to the archaeological resources in the Permian Basin of southeastern New Mexico, now one of the most active of the nation's oil and gas energy fields, has supported more than $\$ 10$ million in field research programs and is poised to be able to fund about $\$ 1$ million in field research annually for the foreseeable future. The financial success of the program is mirrored by the program's outstanding contributions to our understanding of the Permian Basin's long and complex history of human occupation. Surprisingly, although other public lands under the auspices of the BLM are seeing similar rates of energy development, the critical elements of this program have not been picked up elsewhere in the BLM. The Permian Basin program appears doomed to be an example of a "one-off" alternative mitigation solution. The factors barring more widespread adoption include the ebb and flow of energy production activity, complications arising from mixed land status and the ability to work across jurisdictional boundaries, hesitation to change procedures that are working adequately for the time being, and a lack of capacity to institute systemic change.

Keywords: cultural resource management, alternative mitigation, federal undertaking, Permian Basin Programmatic Agreement, federal agency, Bureau of Land Management, programmatic agreement

El programa de mitigación alternativo que la Oficina de Administración de Tierras del Departamento del Interior del los Estados Unidos (BLM) estableció en 2008 para abordar los impactos a los recursos arqueológicos en la Permian Basin del sureste de Nuevo México, ahora uno de los campos de energía de petróleo y gas más activos del país, ha apoyado más de $\$ 10$ millones en programas de investigación de campo y está en condiciones de poder financiar alrededor de \$1 millón en investigación de campo anualmente en el futuro previsible. El éxito financiero del programa se refleja en las contribuciones sobresalientes del programa a nuestra comprensión de la larga y compleja historia de ocupación humana de la Permian Basin. Sorprendentemente, aunque otras tierras públicas bajo los auspicios del BLM están experimentando tasas similares de desarrollo energético, los elementos críticos de este programa no se han recogido en ninguna otra parte de la BLM. El programa Permian Basin parece estar condenado a ser un ejemplo de una solución de mitigación alternativa "única." Los factores que impiden una adopción más generalizada incluyen el flujo y reflujo de la actividad de producción de energía, las complicaciones derivadas del estado mixto de la tierra y la capacidad de trabajar a través de los límites jurisdiccionales, la vacilación para cambiar los procedimientos que están funcionando adecuadamente por el momento y la falta de capacidad para instituir cambio sistémico.

Palabras clavas: gestión de recursos culturales, mitigación alternativa, acción federal, Permian Basin acuerdo programático, agencia federal, oficina de administración de tierras, acuerdo programático

Judging by several critical measures, including research results, educational products, participant satisfaction, and, to this point, longevity, the Permian Basin Programmatic Agreement (PBPA) is an excellent example of alternative mitigation that has been successful for cultural resource management on the public lands of southeastern New Mexico. What we look at here is why this mitigation program has not been adopted elsewhere within the Bureau of Land Management (BLM) for use on the public lands that agency administers. As we use the term here, alternative mitigation acknowledges, first, that adverse effects-especially from major developments-are usually large in spatial and temporal scale when archaeological context is considered. Second, alternative mitigation encompasses many ways to address adverse effects beyond excavation, especially when the scope of the adverse effects is long-standing, cumulative, and not completely known and also when adverse effects impact communities who have special relationships to the affected historic properties. One of the great values of alternative mitigation programs is that they are individually developed to meet very particular circumstances, and that is, of course, one of the reasons they are often called "creative mitigation." We see a number of excellent examples of these "one and done," uniquely adapted programs in this issue. There are circumstances, however, when the conditions that prompted the development of a particular mitigation program are widely shared: the rapid development of oil and gas drilling and extraction operations across the public lands of the American

Advances in Archaeological Practice 8(3), 2020, pp. 307-312

(C) The Author(s), 2020. Published by Cambridge University Press on behalf of Society for American Archaeology. This is an Open Access article, distributed under the terms of the Creative Commons Attribution licence (http://creativecommons.org/licenses/by/4.0/), which permits unrestricted re-use, distribution, and reproduction in any medium, provided the original work is properly cited.

DOI:10.1017/aap.2020.20 
West is one such circumstance. These operations use similar equipment and techniques, have similar siting needs and physical development footprints, and create similar short- and long-term impacts to the archaeological record. We present the following analysis of the Permian Basin program as a case study in how and why programs that might seem to be good models for implementation more broadly fail to make the transition from a one-and-done program to a widely adopted best practice. The lessons we have learned with the Permian Basin program will be of interest to those seeking to create systemic change, whether that change is embodied in alternative mitigation techniques or in a broader understanding of mitigation as an evolving element of cultural resource management.

The Permian Basin program has been described in detail in previous publications in this journal (Larralde et al. 2016; Schlanger et al. 2013). In brief, the voluntary program, which was initiated by the BLM in 2008, allows oil and gas developers to contribute to a research fund in lieu of contracting for a new archaeological survey in selected areas of southeastern New Mexico. The PBPA is a program alternative to the Section 106 process. As described by the Advisory Council on Historic Preservation, program alternatives are "alternatives through which agencies can tailor the Section 106 review process for a group of undertakings or an entire program that may affect historic properties" (2020). This program was developed through consultation and collaboration with the New Mexico State Historic Preservation Office, the Advisory Council on Historic Preservation, the New Mexico Archaeological Council, the Mescalero Apache Tribe, and the energy industry as mitigation for ongoing impacts to archaeological resources in one of the most active oil and gas plays (a group of oil or gas fields in the same region that are controlled by the same set of geologic circumstances) under development in the continental United States today. The reader is urged to refer to the earlier articles to learn more about why the PBPA was developed and to understand the nuts and bolts of how it works. As we learned through the study presented here, however, the reasons it has not been adopted widely have less to do with the finer details of the agreement and its development and more to do with changing management environments and priorities. The entire current agreement document for the PBPA itself, along with applications to use the agreement as well as recent newsletters describing research results, can be found under the Permian Basin Programmatic Agreement tab at https://www.blm.gov/programs/ cultural-heritage-and-paleontology/archaeology/what-we-manage/ new-mexico (accessed April 9, 2020).

Now, some 12 years into program implementation, the PBPA can be considered a success: to date, more than $\$ 20$ million has been contributed to the research fund. The BLM has been able to direct, on average, around $\$ 1$ million per year toward significant research programs in southeastern New Mexico. Nearly all the fieldwork in the PBPA area is done through the mitigation fund, and a consortium of stakeholders-archaeologists, cultural resource managers, tribal representatives, and industry representatives-have worked together to set the research agenda for the region. The mitigation fund has supported archaeological field studies, ethnographic research, educational outreach, publications, data management, and collections and archival research. In addition, the fund has supported the development and regular review of regional research designs and a critical assessment of the impact to archaeological resources under this program in places where known sites within areas proposed for well pads, roads, or other development were avoided but no additional new survey was required. The research component of the agreement in particular has given rise to critical dating studies that have clarified the chronology and demographic prehistory of southeastern New Mexico; geomorphological research that has identified and characterized the nature, extent, and integrity of the archaeological record; significant tribal participation and consultation that have led to the identification of Native American Traditional Cultural Properties and sacred sites; additional fieldwork and archival research into critical settlement types and temporal periods from excavations conducted by avocational groups in the 1960s and 1970s that had not been fully reported; and a major program of documentation, dating, and interpretation of rock art resources. Altogether, these studies have significantly added to and altered our understanding of human occupations in what is now southeastern New Mexico, and we anticipate that ongoing and future research will continue to add to this understanding. All projects funded under the PBPA mitigation fund have been fully reported, and these reports are available in the Digital Archaeological Record (tDAR). The Bureau of Land Management is currently working with tDAR and the research community of the PBPA to add the databases developed during the research work to tDAR's digital archive as well.

The success of this landscape-scale mitigation approach raises several questions: Where else might this approach be useful in furthering our understanding of the archaeological record and cultural resources? Why hasn't this approach been adopted elsewhere within the BLM? And why is it important to look for new ways to manage cultural resources on a landscape scale on public lands?

\section{WHERE ELSE MIGHT THE PERMIAN BASIN APPROACH HAVE EMERGED?}

Figure 1 shows the location of major oil and gas fields in the west and their relationship to the public lands managed by the BLM. The locales most likely to have conditions on the ground that are similar to the Permian Basin include the energy fields in Wyoming, North Dakota, the Uintah Basin and the Paradox Basin in Utah, southwest Colorado, and northwest New Mexico. Here, the overlap between the presence of public lands and oil and gas plays creates the opportunity for some synergy between oil and gas development and archaeological fieldwork.

Figure 2 shows the average number of archaeological surveys required under Section 106 of the National Historic Preservation Act between 2011 and 2018 in the western states with a significant acreage of public lands. In the past 10 years, Wyoming has led the nation in the number of Class III inventory surveys required and conducted each year to meet the BLM's compliance responsibilities under the National Historic Preservation Act. Not coincidently, Wyoming also has the highest rate of oil and gas development among BLM states. New Mexico is a close second, with around 1,500 surveys per year to Wyoming's 1,600-plus, and Utah is a somewhat distant third, with around 450 surveys. Completing the list of states with more than 200 required surveys per year are Montana (and North Dakota, which is administered in association with Montana), Colorado, and California. Not 


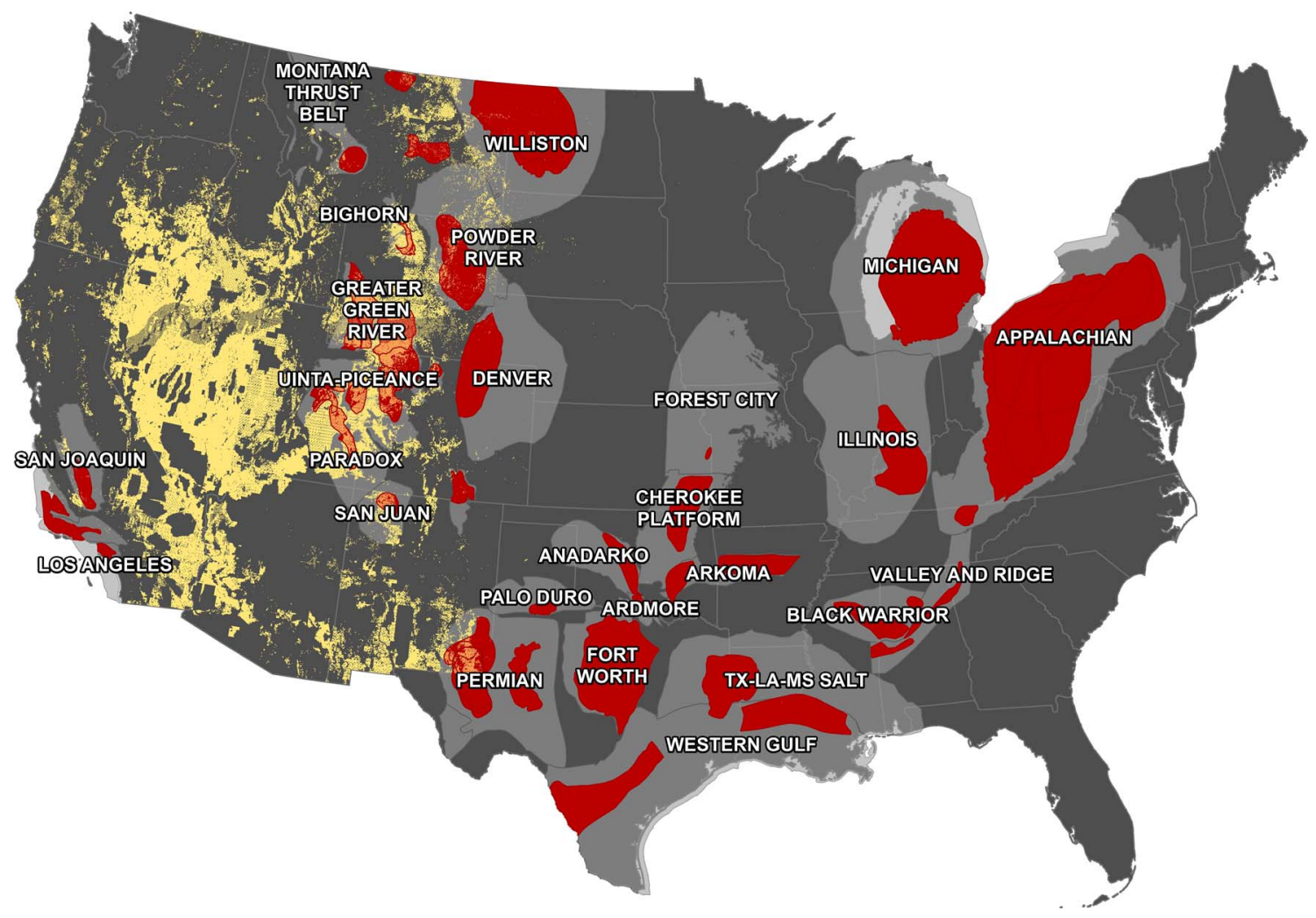

FIGURE 1. Major oil and gas plays in development in the United States. Bureau of Land Management-administered public lands are shown in yellow; major plays are shown in red (courtesy of Kelsey Crocker, Bureau of Land Management, New Mexico State Office).

surprisingly, these states all include significant oil and gas plays. These oil and gas states (termed "the OPEC states" within BLM) are also often attractive locales for other energy development projects, including wind and solar energy, energy transmission lines, and pipelines, all of which involve putting archaeological inventory crews on the ground. The demand for Section 106 surveys in the remaining BLM states (Alaska, Arizona, Idaho, Nevada, Washington, and Oregon) to date has been driven by concerns other than oil and gas development.

Permian Basin-like approaches, which address impacts on a landscape scale and which attempt to account for ongoing indirect and cumulative impacts to cultural resources and cultural landscapes, did emerge in three of the OPEC states-Wyoming, New Mexico, and California. Two of these lacked the staying power of the PBPA, and the third has yet to be fully implemented. These three are briefly detailed below.

In the late 1980s, the Fruitland Gathering System program was developed to mitigate the impact of more than 600 miles of pipeline needed to serve coal-bed methane wells operated by six different energy companies in northwest New Mexico. The design of the Fruitland project, which called for excavations at a sample of 59 sites as well as some targeted new archaeological survey, grew out of the project directors' experience with the Dolores Archaeological Program of the late 1970s (Breternitz et al. 1987) and owes much as well to earlier programs associated with the
River Basin Surveys (see Banks and Czaplicki [2016] for a good overview). The programmatic agreement was finalized in 1989 and resulted in a leap forward in our understanding of Dinétah (early Navajo) archaeology. The BLM had difficulties in obtaining final reports, and a synthesis was finally completed only in 2014, some 18 years after the last excavations.

In the 1990s, Wyoming BLM archaeologists negotiated an agreement with independent energy companies to contribute some $500 \mathrm{~m}^{2}$ of excavation per year in the Jonah Field to mitigate the impacts of extraordinarily dense and rapid gas well development (well over 1,500 wells have been drilled in the Jonah Field, one of the locations to see the widespread use of fracking to develop productive wells). This agreement was initiated in 1993 and amended twice before it expired in 2017. As with the Fruitland program, the agreement resulted in several critical studies but also a large backlog of uncompleted reports.

Most recently, interest in developing the California Desert landscape for solar energy production and energy transmission has set the stage for the most ambitious program of mitigation for landscape-scale direct, indirect, and cumulative impacts. The Desert Renewable Energy Conservation Plan Programmatic Agreement covers some 22.5 million acres and is based in an effort to target development on lands with the least impacts to cultural resources. The programmatic agreement calls for the identification of areas of high cultural sensitivity to aid in project 


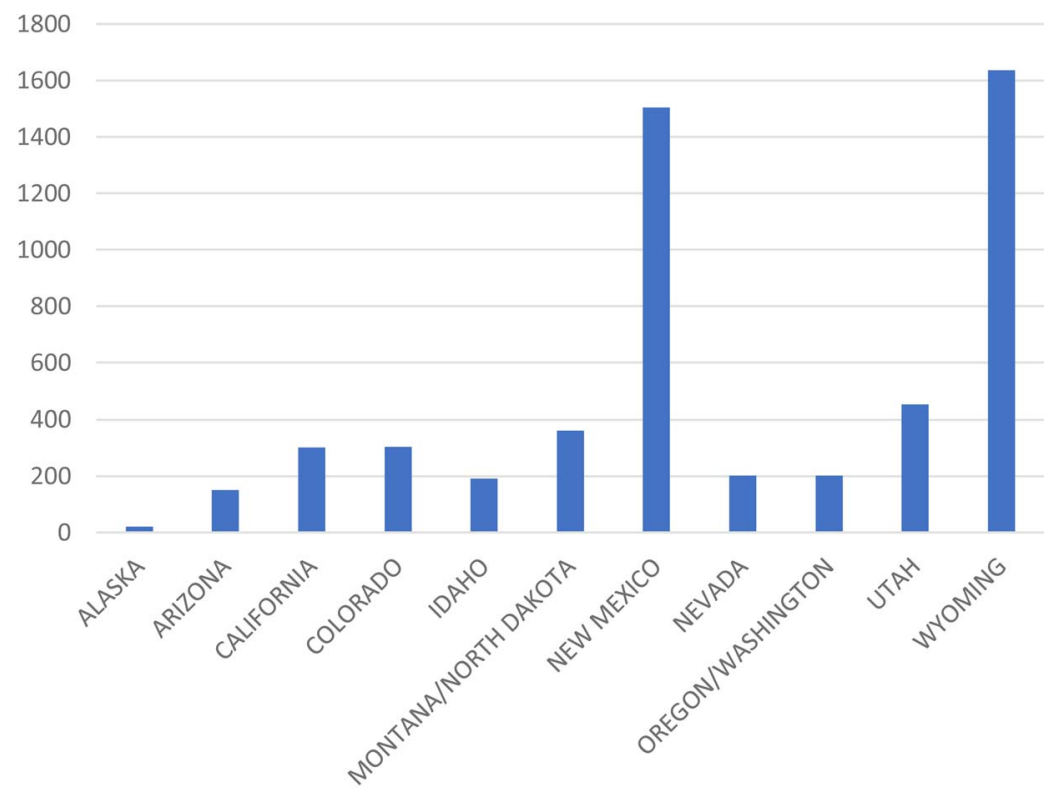

FIGURE 2. Average number of archaeological surveys required per year by the Bureau of Land Management under Section 106 of the National Historic Preservation Act between 2011 and 2018 (data provided by Ranel Capron, Federal Preservation Officer, Bureau of Land Management, Washington, DC).

planning and sets up a fee structure, on a project-by-project basis, for mitigating cumulative and indirect effects. The mitigation includes consideration of tribal benefits and public education benefits as well as contributions to professional archaeological knowledge. Implementation of the programmatic agreement is still in its very early stages, but the inclusion of tribes and tribal concerns and the resulting acknowledgment by the BLM and project applicants that the California Desert region is a living spiritual landscape for the Colorado River Indian Tribes is a major accomplishment and one that largely distinguishes this approach from its predecessors.

\section{WHAT CONDITIONS MIGHT MOST EASILY SUPPORT A SUCCESSFUL LANDSCAPE-SCALE MITIGATION PROGRAM?}

We have identified several conditions that appear to support the development and success of landscape-scale mitigation programs in the western states on public lands. The first is rapid and intense development pressure that targets large blocks of public lands. Energy development tends to be episodic and urgent. During booms, applications for public land use rise dramatically, and the BLM's response systems are stressed; during busts, the BLM attempts to recover from staff burnouts and system overloads. Whether the energy is produced by solar fields, oil fields, or gas fields, the boom and bust patterns create both an impetus for system change and a resistance to system change. A second condition is the ubiquitous distribution of cultural resources that cannot be easily avoided by altering project design and the related consequence of cultural resources at risk of repeated damage from ongoing direct effects, indirect effects, and cumulative effects. Under these circumstances, National Register-eligible sites cannot be avoided, either because of previous development or because of the nature of the distribution of archaeological resources. When sites cannot be avoided, adverse effects must be mitigated, and the mitigation costs are more easily predicted, managed, and controlled through a landscape-level programmatic agreement. The third condition is a previously developed solid baseline archaeological record derived from numerous Class III pedestrian surveys. In areas where archaeologists have been able to carry out enough inventory survey to feel confident that they understand the character and distribution of the surface archaeology, they can more easily envision a mitigation program informed by models of archaeological site distributions derived from a solid sampling base.

\section{WHAT THE FIELD SAYS ABOUT ADOPTING LANDSCAPE-SCALE MITIGATION PROGRAMS}

There are no landscape-scale pooled mitigation programs for oil and gas development currently in Wyoming, Montana, North Dakota, Utah, California, Colorado, or the San Juan Basin of New Mexico. Nor are there any in use for areas with multiple wind projects; nor do we see them in use in the rapidly developing solar fields in Nevada, although the BLM is encouraging the development of Solar Energy Zones in Nevada, Arizona, Utah, Colorado, and New Mexico. Nevada is experiencing situations where indirect and cumulative effects are significant and can no longer be avoided, especially with the multiplication of transmission lines headed into energy hubs south of Las Vegas. To date, the Nevada $B L M$ is handling these effects on a project-by-project basis. 
We interviewed BLM archaeologists in California, Montana and the Dakotas, Colorado, and southwestern Wyoming to understand why this might be the case (BLM staff, interviews by Signa Larralde, 2019). The most common response we received when discussing the Permian Basin program with potential adopters was "if only we had time to work on an agreement like that." We need only refer to Figure 2, the average number of archaeological surveys required each year in the busier states, to see that the administrative burden of reviewing reports and environmental assessments is very high indeed. We understand that agreements may take a considerable time commitment. Even if a substantial initial time investment is needed, we would argue that the payoff in reduced review times and other benefits (which have included major research projects yielding new information from the archaeological record) more than makes up for the initial time investment.

The workload may be lessening slightly in BLM oil and gas offices throughout the west, but this simply decreases the pressure to work up a new program. And that brings up the second-most common response: the current compliance procedures are working well enough, partly due to the streamlining offered by the ways in which the BLM consults with state historic preservation offices, that there is little pressure to negotiate a different process. Staffing plays a role here as well. The Permian Basin program is managed by a full-time staffer. Most BLM offices do not have the capacity to move staff from their current jobs to full-time management of a mitigation program.

Other factors affecting the development of a significantly different process include the need to conserve other resources such as the greater sage grouse habitat. In this case, requiring developers to cut down on habitat fragmentation by concentrating development, such as oil and gas wells, in smaller areas reduces the need for archaeological survey. That in turn lessens the pressure to adopt a different management strategy and a different approach to mitigation. Yet another factor is the increased scrutiny that oil and gas environmental assessments have come under recently. In Utah and the San Juan Basin of northwestern New Mexico, stakeholders are calling for more inventory, more identification of cultural resources, and more consultation. This has slowed efforts to engage in developing a programmatic agreement for mitigating direct impacts, let alone indirect and cumulative impacts. This situation may change as stakeholders develop a higher level of trust in one another, but at present, the perceived conflicts between highly valued cultural resources and landscapes and developing oil, gas, wind, and solar fields are leading to litigation efforts rather than mitigation programs.

The final factor that came up in discussions with BLM archaeologists was the idea that there had not been sufficient fieldwork accomplished in some areas to support the kind of trade-off between new or additional archaeological inventory and directed field research that is at the heart of the Permian Basin program. The baseline for including public lands within the Permian Basin research program was that at least $10 \%$ of the surface had been professionally surveyed. Most of the contiguous area that met this criterion had well over $20 \%$ survey coverage, and some portions had more than $30 \%$ survey coverage of the modern surface. In a practical sense, however, it is not the amount of survey coverage that is critical here but rather the ability to synthesize records, create robust models, and feel comfortable with the current understanding of the distribution and character of the surface record. Once the distribution of materials on the surface is sufficiently clear, we can consider moving on from recording many more similar surface distributions to archaeological investigations that answer more complex questions.

\section{MITIGATION PROGRAMS AND CULTURAL RESOURCE MANAGEMENT ON PUBLIC LANDSCAPES}

The idea behind the PBPA was for the BLM and the archaeological community working in southeastern New Mexico to change how we learn from the archaeological record over the course of the development of an active oil and gas energy field. In doing so, the BLM acknowledged that the status quo-continuing to conduct archaeological inventory surveys in an area where our understanding of the surface archaeology had ceased to change in any meaningful way-was not serving archaeological interests. And, of course, knowing where sites were did not eliminate damage to them and so did not meet the BLM's conservation or preservation missions. There can be no argument that we have learned a great deal about the past of the Permian Basin during the decade in which the PBPA has been in effect. The research projects funded under the PBPA mitigation fund have substantially altered and improved our understanding of the archaeological record of New Mexico. This in turn allows us to refine and enhance our future research designs, make better assessments of resource values, and make better management decisions about the archaeological resources of southeastern New Mexico. What is not clear is whether learning more about the archaeology of landscapes that are being transformed through modern energy development is of enough value to the BLM to adopt similar programs in other energy development fields. We believe it is.

Making the change to a landscape-level mitigation program requires a good deal of commitment and investment from local personnel, state historic preservation offices, the archaeological community, the historic preservation community, descendant populations and Native communities, and, of course, agency administrators. We believe that investment is overdue. Once we have recorded the distribution of surface materials, made allowances for the presence of subsurface deposits, and attempted to place new development where we have the least risk of disturbing surface or subsurface deposits, have we met our obligations to identify and evaluate archaeological resources? Have we met our professional obligation to promote study of the past? And in the context of federal agency cultural resource management, have we met the intent of Congress, in the National Historic Preservation Act of 1966, as amended through 1992, when it found that

the increased knowledge of our historic resources, the establishment of better means of identifying and administering them, and the encouragement of their preservation will improve the planning and execution of federal and federally assisted projects and will assist economic growth and development; and... [that] it is nevertheless necessary and appropriate for the Federal Government to accelerate 
its historic preservation programs and activities [16 USC 470 Sec. 1 (b) (6 and 7)]?

We believe we have not.

We have robust samples of the surface archaeology of much of the west, even if we do not always have the 40-plus-year record of the Permian Basin. And the slow but steady erosion of the archaeological record that we see in the Permian Basin is not unique either. The approach we have taken in the Permian Basin has evolved from finding sites, to avoiding sites, to acknowledging that damage is continuing, to finding a way to keep learning from the archaeological record even while we continue to approve additional development. This innovative approach should not be an evolutionary "one-off." What, after all, is preserved when we stop learning from and adding to our understanding of the past? The landscapes of the west are changing rapidly; we call upon the fields of archaeology and historic preservation to push for change in how we manage our cultural resources and preserve the opportunity for greater understanding for this generation as well as those to come.

\section{Acknowledgments}

All three of us, formerly archaeologists and cultural resource managers for the Bureau of Land Management (BLM), are now retired. This article represents our views and is not intended to represent the views of the BLM. We appreciate the patience and generosity of the BLM archaeologists who consented to be interviewed for this article and give our thanks especially to Matt Basham, Ranel Capron, Buck (George) Damone, Sam Drucker, Geoffrey Haymes, Bryan Hockett, Tony Overly, Gary Smith, Dave Simons, Scott Stadler, and Nate Thomas for their help in understanding the issues surrounding the development of constructive mitigation programs. We would especially like to honor the memory of Sam Drucker, who provided information for this article while ill. We extend our thanks to the two anonymous reviewers for their careful reading of the article and their thoughtful comments. Kelsey Crocker, Bureau of Land Management, New Mexico State Office, drafted Figure 1. Ranel Capron, Federal Preservation Officer, Bureau of Land Management, Washington, DC, provided the data on undertakings and inventory surveys presented in Figure 2 .

\section{Data Availability Statement}

No original data were presented in this article. The data illustrated in Figure 2 were provided by Ranel Capron, Federal Preservation Officer, Bureau of Land Management, Washington, DC. Notes from personal interviews with Bureau of Land Management staff are available on request from Signa Larralde.

\section{REFERENCES CITED}

\section{Advisory Council on Historic Preservation}

2020 Program Alternatives. Electronic document, https://www.achp.gov/ program_alternatives, accessed February 25, 2020.

Banks, Kimball M., and Jon S. Czaplicki (editors)

2016 Dam Projects and the Growth of American Archaeology: The River Basin Surveys and the Interagency Archeological Salvage Program. Routledge, Oxford.

Breternitz, David A., G. Timothy Gross, and Christine K. Robinson (compilers)

1987 Dolores Archaeological Program: Final Synthetic Report. U.S. Department of the Interior, Bureau of Reclamation, Engineering and Research Center, Denver, Colorado.

Larralde, Signa, Martin Stein, and Sarah H. Schlanger

2016 The Permian Basin Programmatic Agreement after Seven Years of Implementation. Advances in Archaeological Practice 4:149-160.

Schlanger, Sarah H., George MacDonell, Signa Larralde, and Martin Stein

2013 Going Big: The Permian Basin Memorandum of Agreement as a Fundamental Shift in Section 106 Compliance. Advances in Archaeological Practice 1:13-23.

\section{AUTHOR INFORMATION}

Sarah H. Schlanger $\square$ (sands71550@gmail.com, corresponding author) and Signa Larralde 1 Independent Researchers, 23 Chusco Road, Santa $\mathrm{Fe}$, New Mexico 87508 USA

Martin Stein Independent Researcher, 4399 Organ Mesa Loop, Las Cruces, New Mexico 88011 USA 